\title{
Who needs a genome ethics treaty?
}

\section{- Little concensus at international conference - Could Germany's strict laws become model?}

\section{Bethesda, Maryland}

Is the world ready for an international treaty to regulate the use of genome research? Not just yet, judging by a conference on the ethical and social issues raised by the human genome project, held at the National Institutes of Health (NIH) last week.

The conference, sponsored by the NIH National Center of Human Genome Research, brought bioethicists and policymakers from around the world together with leaders from the US, Japanese and Soviet genome programmes. Unlike many previous $\mathrm{NIH}$-funded genome ethics meetings, last week's gathering looked specifically at the need for an international genome ethics treaty. But with opinion sharply divided largely along national lines - the group could resolve only to set up a series of international task groups to debate the issues further.

Peter Singer from Monash University in Australia, head of the newly formed International Association of Bioethics, questioned the goal of attaining a genome ethics convention signed by as many nations as possible. As long as there are large differences in ethical opinion from country to country, he said, an international treaty will achieve little, with vague wording reflecting only "a superficial level of agreement".

These differences in opinion are huge. For instance, the German Bundestag, sensitive to the suggestion of a revival of Nazi eugenics policies, voted last year to allow screening of embryos only for couples at risk of passing on severe sex-linked disorders, such as Duchenne muscular dystrophy (see Nature 348, 8; 1990).

Germany has also banned any attempts at human germ-line manipulation, by a unanimous vote of the Bundestag, says Michael Catenhusen, an opposition Social Democrat and chairman of the Bundestag's Science and Technology Committee. Feelings run so high that conferences in Germany to discuss bioethics have been called off, for fear of disruption by demonstrators from environmentalist, far-left and anarchist groups.

Asked about the prevailing attitude to genetic screening in Germany, James Watson, head of the NIH genome programme, said he could not see how a developed nation can continue being "backward", denying pre-implantation genetic screening for couples at risk of having children with genetic diseases, simply "by invoking the name of Hitler".

Catenhusen maintains that Germany's laws will become the model for the rest of the world. But that seems unlikely - even within Europe, other countries have already passed far less restrictive laws governing genetic screening. And many of the geneticists attending last week's meeting were wary of strict legislative controls, at least so far as research is concerned. Lev Kisselev, from the Soviet Academy of Sciences in Moscow, hardened by the manipulation of Soviet biology under Lysenko said he was opposed to any interference with research by "noncompetent" people.

So far, the 25-nation Council of Europe, a body strongly concerned with human rights issues, is the only international organization planning to negotiate a bioethics treaty. The Council of Europe convention will contain a number of protocols, each dealing with a specific area -- such as medical research and the trade in body organs for transplantation. Countries will be able to ratify the convention à la carte, choosing to obey whichever protocols they choose.

But there are no plans yet for a protocol on ethical aspects of the genome project, and Frits Hondius, deputy director for legal affairs at the Council of Europe, is not convinced that there is a strong need for one. In any case, the Council of Europe may not be the best forum for an international genome ethics treaty when the two major players in genome research are the United States and Japan.

The task groups set up by last week's meeting will be looking at a number of key issues, including the use of genetic information to discriminate against individuals in employment and when arranging insurance, and the protection of genetic data stored in forensic databases. The task groups will eventually report to a steering committee made up of experts from each of the major committees around the world now struggling with genome ethics - including those from the European Communities, the Human Genome Organization, the Council of Europe, and the US, Soviet and Japanese genome programmes.

This new steering committee, which will itself tackle the divisive issue of the clinical uses of genome research, is seen by many delegates to last week's NIH meeting as the most positive development. Even if no international treaties are drafted, more dialogue between the various committees will help to prevent them duplicating each other's work and "reinventing the wheel", says Nancy Wexler, who chairs the joint NIH/Department of Energy genome ethics working group.
Space station back on track

\section{Washington}

THE threat to cancel the US-led space station Freedom (see Nature 351, 428; 6 June 1991) has subsided, at least for the time being, after the full House of Representatives voted last Thursday to provide $\$ 1,900$ million for the station in the 1992 fiscal year. The decision reversed that of the House Appropriations Committee, which had included only $\$ 100$ million for Freedom in 1992, barely enough to close the project down.

The House decision, passed by 240 votes to 173 , would freeze the overall 1992 budget of the National Aeronautics and Space Administration (NASA) at its 1991 level. This should keep the space station project on course, but could delay science missions such as the Cassini Saturn probe and the CRAF cometary probe (which for budgetary purposes are packaged as a single mission), due for launch in 1995 and 1996 respectively, and the $\$ 40,000$ million Earth Observing System remote sensing programme. Spending on these two projects was scheduled to accelerate during the coming year.

In the case of CRAF/Cassini, where the 1992 budget request of $\$ 328$ million was more than twice that of 1991, the proposed budget freeze could even force cancellation, says Dale Cruikshank, chairman of the American Astronomical Society's Division of Planetary Sciences. There are only a limited number of dates on which the two probes can be launched to achieve their missions, and long delays will increase costs drastically.

The battle over NASA's budget now moves to the Senate. Last year, the Senate restored some threatened cuts to NASA's budget, in a compromise worked out between the House and Senate, which saved CRAF/Cassini. The Senate is expected to be tougher this year, however, so it is unlikely that all of NASA's proposed space science projects will be funded in full.

Last week's endorsement of the space station in the House followed intensive lobbying to save Freedom by President George Bush's administration. Bush himself is said to have telephoned key members of Congress to canvass their support, and Richard Darman, director of the White House Office of Management and Budget, told the pro-station House Committee on Science, Space and Technology last week that killing Freedom would not increase spending on other science projects. On previous occasions, when Congress cut money from the President's budget request for the Superconducting Super Collider, he said, the funds were reallocated to water projects, not science. Darman also said that Bush's senior aides would advise the President to veto any congressional attempt to cancel the space station. PeterAldhous 